Check for updates

Cite this: Mater. Chem. Front., 2020, 4, 2040

Received 6th April 2020,

Accepted 20th May 2020

DOI: $10.1039 / \mathrm{d} 0 \mathrm{qm} 00218 \mathrm{f}$

rsc.li/frontiers-materials

\title{
Optimized synthesis of fluorinated dithienyl-diketopyrrolopyrroles and new copolymers obtained via direct heteroarylation polymerization $\uparrow$
}

\author{
Marius Mamone, ${ }^{a}$ Thomas Bura, ${ }^{a}$ Samuel Brassard, ${ }^{a}$ Eliane Soligo, ${ }^{a}$ Keqiang $\mathrm{He},{ }^{b}$ \\ Yuning $\mathrm{Li}$ (D) ${ }^{\mathrm{b}}$ and Mario Leclerc (D) *a
}

\begin{abstract}
Diketopyrrolopyrrole-based (DPP-based) polymers are a very important class of materials for both organic solar cells (OSCs) and organic field-effect transistors (OFETs). Here we report an optimised synthesis of fluorinated dithienyl-diketopyrrolopyrrole (fDT-DPP) and three new highly fluorinated fDTDPP-based materials obtained from direct heteroarylation polymerization (DHAP). This study confirms the properties of the fluorine atom in a polymer, activation of the $\alpha$-position hydrogen on thiophene moieties, decreasing HOMO and LUMO energy, lower bandgaps and modification of the solubility and morphology of the materials.
\end{abstract}

\section{Introduction}

Since the first report on the synthesis of 3,6-diphenyl, 2,5-dihydropyrrolo[3,4-c]pyrrole-1,4-dione by Farnum et al. in $1974,{ }^{1}$ DPPbased $\pi$-conjugated polymers have been extensively studied due to their good performance in both organic solar cells $(\mathrm{OSCs})^{2}$ and organic field-effect transistors (OFETs). ${ }^{3,4}$ Modifications of the aromatic moieties can highly modulate the electro-optical properties of the resulting copolymers and, in particular, dithienyl-DPP (DT-DPP) has attracted increasing interest. ${ }^{5,6}$ Fluorination of the conjugated backbone has also proven to be effective to fine-tune the properties of these organic materials. ${ }^{7-11}$ The electronegativity of the fluorine atom lowers both the HOMO and LUMO energy levels without creating additional steric hindrance. ${ }^{12,13}$

Recently, our group has developed a fluorinated DT-DPP and reported fDT-DPP copolymers obtained via direct heteroarylation polymerization (DHAP), which showed very promising performance in OFET. ${ }^{14}$ The fDT-DPP was obtained by classical condensation of diisopropyl succinate with 4-fluoro-2-cyanothiophene as a key intermediate in 6 steps with a satisfactory $21 \%$ overall yield (Scheme 1, eqn (1)). Nevertheless, this synthetical pathway was not easily applicable to the large-scale preparation of this important monomer. Very recently, Wang et al. proposed a nonconventional stepwise synthesis of symmetrical and

${ }^{a}$ Canada Research Chair on Electroactive and Photoactive Polymers, Department of Chemistry, Université Laval, Quebec City, Quebec G1V 0A6, Canada.

E-mail: mario.Leclerc@chm.ulaval.ca

${ }^{b}$ Department of Chemical Engineering, University of Waterloo, Waterloo, Ontario N2L 3G1, Canada

$\dagger$ Electronic supplementary information (ESI) available. See DOI: 10.1039/d0qm00218f
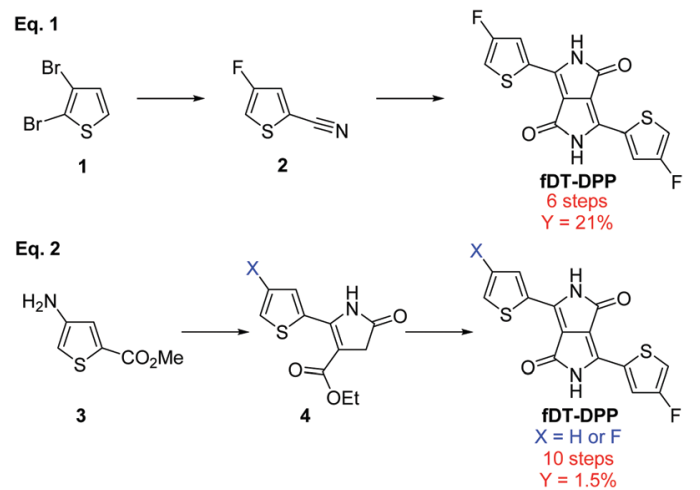

Scheme 1 Previous synthesis of fDT-DPP by Leclerc's group (eqn (1)) and Wang's group (eqn (2)).

non-symmetrical fDPP and confirmed the properties of fDT-DPP copolymers (Scheme 1, eqn (2)). ${ }^{15}$ To fully study the potential of this monomer, we report here optimisation of its synthesis and application to new highly fluorinated DPP based copolymers.

\section{Results and discussion}

\section{Optimization of fDT-DPP synthesis}

As shown in Scheme 2 and based on our previous studies, ${ }^{14}$ 3-bromo-2-(dimethyloctylsilyl)thiophene (5) was synthesized from a lithiation reaction of commercially available 2,3-dibromothiophene (1) in diethyl ether (at $\left.-78{ }^{\circ} \mathrm{C}\right)$ followed by addition of $n$-octyldimethylchlorosilane and isolated after reduced pressure distillation in $85 \%$ yield. 

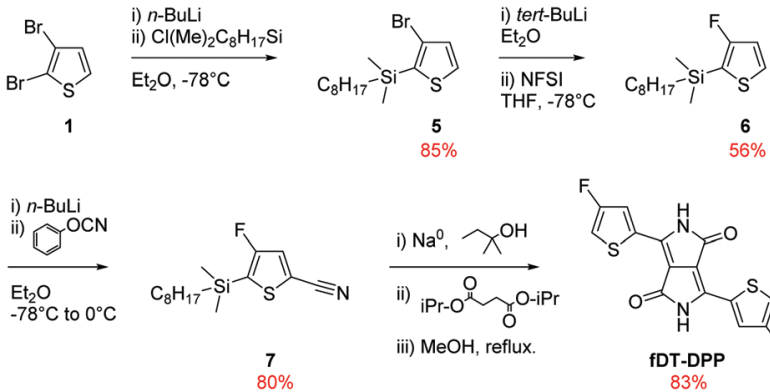

iii) $\mathrm{MeOH}$, reflux. $80 \%$

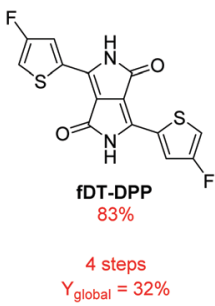

Scheme 2 New fDT-DPP synthesis in 4 steps

The fluorination of compound (5) was the most delicate step in our previous synthesis due to the difficulty in separating hydrogenated and fluorinated thiophene by classical chromatography on silica gel. The reaction had to be realized at $-100{ }^{\circ} \mathrm{C}$ to obtain a good selectivity for the fluorinated product which is very limiting for application in large scale synthesis. To solve these problems, tert-BuLi was used instead of $n$-BuLi for the monolithiation of compound (5) followed by a dropwise addition of a cold solution of NFSI in THF to increase the solubility of the fluorine donor. The reaction can now be realised at $-78{ }^{\circ} \mathrm{C}$, a more easily processable temperature, and a better conversion was observed due to the highest reactivity of tert-BuLi. The purification was also easier and the reaction can be applied at a larger scale with high purity and a very satisfying $56 \%$ yield.

As described later, compound (6) is also an important intermediate for the synthesis of various fluorinated bithiophene units.

Compound (6) could then be converted to compound (7) by a direct cyanation reaction with phenyl cyanate with $80 \%$ yield. This procedure reduces by one step the usual formylation/cyanation pathway. Finally, DPP was obtained by a classical cyclization with isopropyl succinate following an already described procedure. $^{16}$ Due to the volatility of fluorinated thiophene, silylated compound (7) was directly used in this transformation and the product was deprotected in situ by quenching the reaction with dry $\mathrm{MeOH}$. The desired fDT-DPP was isolated with $83 \%$ overall yield. These optimizations increased the global yield of the synthesis to $32 \%$ and reduced the number of steps to 4 .

\section{Design of fDT-DPP-based copolymers}

To pursue our study on fluorine atom effects on the properties of fDT-DPP-based copolymers, several new monomers (see Schemes 3 and 4) and conjugated copolymers (see Scheme 5) were designed and investigated for their properties in OFETs. Their structures were chosen according to a recent work published by Wang et al. ${ }^{17}$ on non-fluorinated DPP analogs.

\section{Monomer preparation}

Due to the known low solubility of fluorinated conjugated polymers and with the aim of making a relevant comparison with Wang's work, ${ }^{17}$ large branched 4-octadecyldocosyl and

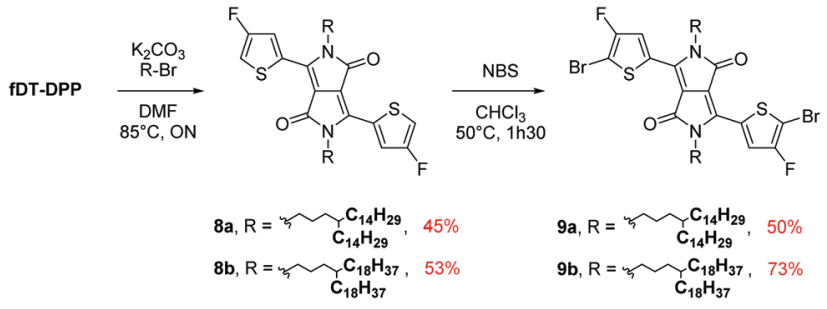

Scheme 3 Alkylation and bromination of fDT-DPP.

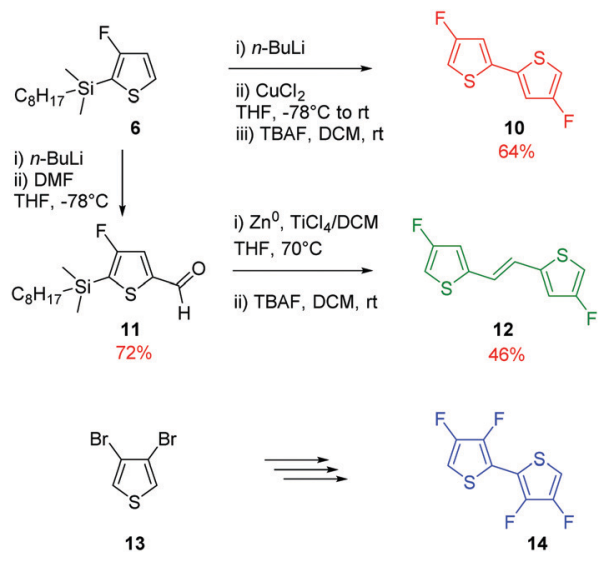

Scheme 4 Preparation of fluorinated comonomers.

4-pentadecylnonadecyl side chains were introduced on fDTDPP in DMF in the presence of $\mathrm{K}_{2} \mathrm{CO}_{3}$ with 45 and $53 \%$ yield. Alkylated fDT-DPP was then brominated by $N$-bromosuccinimide at $50{ }^{\circ} \mathrm{C}$ in degassed chloroform to obtain the corresponding monomers (9) in 73 and $50 \%$ yields, respectively (Scheme 3).

As reported in Scheme 4, monomer (10) and new monomer (12) were also easily prepared from compound (6) by direct oxidative coupling with $\mathrm{CuCl}_{2}$ with $64 \%$ yield or by formylation followed by a McMurry condensation with a $46 \%$ overall yield. $3,3^{\prime}, 4,4^{\prime}$-tetrafluoro-2,2'-bithiophene (14) can be prepared from 3,4-dibromothiophene following previously described procedures. ${ }^{18}$

\section{Polymer synthesis}

After optimizations (see the ESI $\dagger$ ), copolymers P1, P2 and P3 (Scheme 4) could be prepared by direct (hetero)arylation polymerization (DHAP) using $\mathrm{Pd}(\mathrm{OAc})_{2}$ in a toluene/DMAc mixture at $120{ }^{\circ} \mathrm{C}$ for $16 \mathrm{~h}$. After precipitation in methanol, the polymers were purified by successive Soxhlet extractions. The molecular weights of the resulting polymers were measured by high temperature size exclusion chromatography (SEC) with polystyrene as standard and 1,2,4-trichlorobenzene as the eluent at $110{ }^{\circ} \mathrm{C}$ and the results are listed in Table 1 . Surprisingly, in all cases, $M_{\mathrm{n}}$ is significantly lower than the non-fluorinated analogs described by Wang et al. ${ }^{15}$ even with longer reaction times. Clearly, fDT-DPP monomers are highly reactive towards DHAP polymerization but the brominated ones are by far less reactive. $^{14}$ 

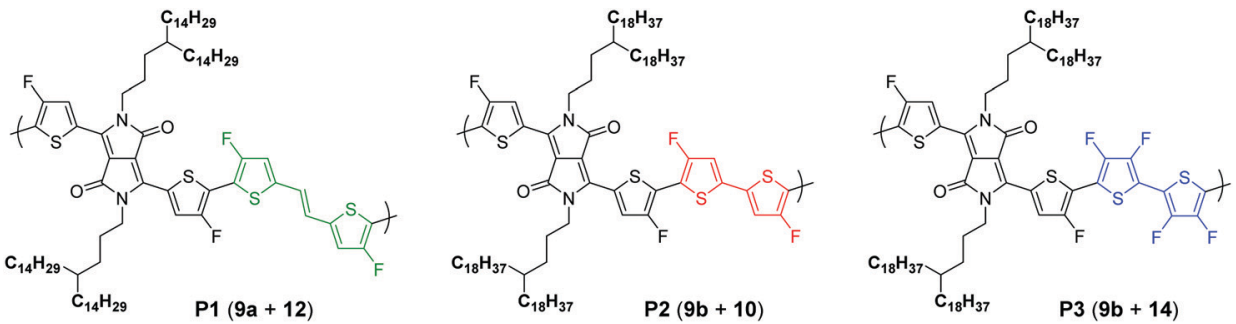

Scheme 5 fDT-DPP-based copolymers synthesized by DHAP.

The difference could also be explained by a higher rigidity induced by the fluorine atom on the DT-DPP moiety which reduces the solubility of the resulting copolymers.

\section{Polymer characterization}

These polymers show good thermal stability with $5 \%$ weight loss temperature above $400{ }^{\circ} \mathrm{C}$ (see the ESI $\dagger$ ). As described for the non-fluorinated analogues, broad thermal transitions between $\sim-10$ and $40{ }^{\circ} \mathrm{C}$ have been observed in the DSC curves, which are probably related to the melting of the long alkyl side chains (see the ESI $\dagger$ ). ${ }^{19}$

\section{Optical absorption and electrochemical properties}

As observed by Wang et al., ${ }^{17}$ the more electron-rich nature of bis-thienylethene relative to the bithienyl group leads to a slightly red shifted maximum of absorption for P1 at $806 \mathrm{~nm}$ compared to $791 \mathrm{~nm}$ for $\mathbf{P 2}$ (see Table 1 and Fig. 1). It could also explain the decrease of energy levels moving from -5.35 to $-5.51 \mathrm{eV}$ for the HOMO and from -3.43 to $-3.54 \mathrm{eV}$ for the LUMO for P1 and P2, respectively. As expected, addition of a fluorine atom on the conjugated backbone decreased the energy level. If one compares $\mathbf{P 2}$ and the non-fluorinated DT-DPP analogue P4F2T-C40, ${ }^{17}$ we can see that the position of the fluorine atom on the skeleton has very little impact on the optical and electrochemical properties of the polymer. In fact, the absorbance maxima are similar, 791 and $799 \mathrm{~nm}$, the HOMO and LUMO energy levels have slightly changed and the electrochemical bandgaps are very close.

Interestingly, the addition of extra fluorine atoms has significant effects. The absorption maximum of $\mathbf{P 3}$ is blue-shifted by $28 \mathrm{~nm}$ in comparison to $\mathbf{P 2}$ and the HOMO and LUMO energy levels are both lowered. One can notice a decreased optical band gap for $\mathbf{P} 3$ and no secondary absorption shoulder in the UV-vis absorption spectrum in film or in solution.

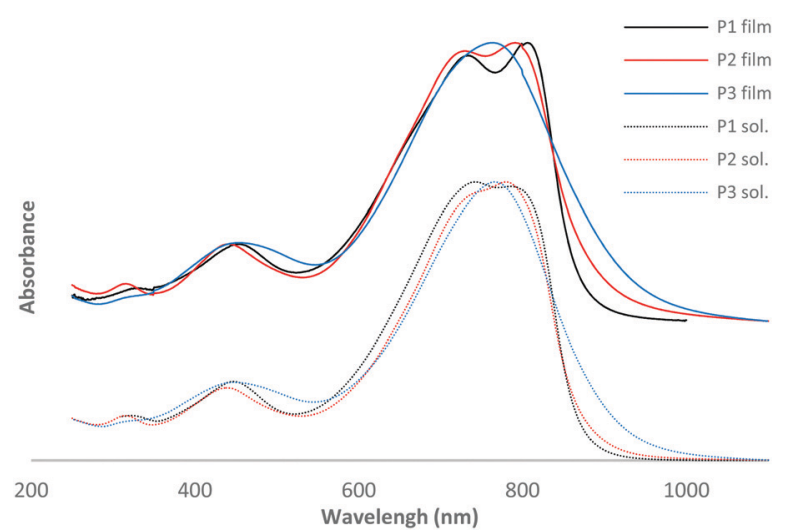

Fig. 1 Normalized UV-vis absorption spectra of the polymers in thin films and in chloroform solution.

\section{Film morphology}

The film microstructures play important roles in determining the device performances. Therefore, two-dimensional grazingincidence X-ray diffraction (2D-GIXD) (see the ESI $\dagger$ ) was performed and the results are depicted in Fig. 2.

From the out of plane line-cuts, (100) and (200) diffraction peaks were observed for spin-coated thin films of all these three polymers, indicating that all of them adopt edge-on packing with respect to the substrate plane in thin films, which was preferred for charge transportation in OFET devices. The lamella packing $d$-spacings of P1, P2 and P3 were 27.2, 32.2 and $31.9 \AA$ A, respectively. P1 showed a higher (100) diffraction peak than that of $\mathbf{P 2}$ or $\mathbf{P 3}$, suggesting that $\mathbf{P 1}$ has much higher crystallinity compared to the other two polymers, which was beneficial for charge transport in the thin films. Unfortunately, no in-plane diffraction peaks were found in the films of all these three polymers, indicative of their lower packing order in the in plane direction, which may be an explanation for the

Table 1 Optical and electrochemical properties of the polymers

\begin{tabular}{lllllllllll}
\hline Polymer & $\mathrm{Mn}(\mathrm{kDa})$ & $D$ & Yield $(\%)$ & $T_{\mathrm{d}}\left({ }^{\circ} \mathrm{C}\right)$ & $\lambda_{\text {max,abs }}(\mathrm{nm})$ film & $E_{\mathrm{g}}^{\mathrm{opt} a}(\mathrm{eV})$ & $\mathrm{HOMO}^{b}(\mathrm{eV})$ & $\mathrm{LUMO}^{\mathrm{cv} b}(\mathrm{eV})$ & $E_{\mathrm{g}}^{\mathrm{cv} c}(\mathrm{eV})$ & $\mathrm{LUMO}^{\mathrm{opt} d}(\mathrm{eV})$ \\
\hline P1 & 16 & 2.7 & 81 & 390 & 806 & 1.43 & -5.35 & -3.43 & 1.92 & -3.92 \\
P2 & 23 & 1.5 & 74 & 395 & 791 & 1.41 & -5.51 & -3.54 & 1.97 & -4.10 \\
P3 & 22 & 1.8 & 82 & 400 & 763 & 1.31 & -5.60 & -3.62 & 1.98
\end{tabular}

${ }^{a}$ The optical bandgaps $\left(E_{\mathrm{g}}^{\mathrm{opt}}\right)$ calculated from the film absorption onsets. ${ }^{b}$ HOMO and LUMO energy levels were calculated according to $E_{\mathrm{HOMO}}=-\left(4.80+E_{\mathrm{onset}}^{\mathrm{Ox}}\right) \mathrm{eV}$ and $E_{\mathrm{LUMO}}=-\left(4.80+E_{\mathrm{onset}}^{\text {red }}\right) \mathrm{eV}$, in which $E_{\text {onset }}^{\mathrm{ox}}$ and $E_{\text {onset }}^{\text {red }}$ represent oxidation and reduction onset potentials of the polymers versus $\mathrm{Fc} / \mathrm{Fc}^{+}$, respectively. ${ }^{c}$ Calculated according to $E_{\mathrm{g}}^{\mathrm{cv}}=E_{\mathrm{HUMO}}-E_{\mathrm{LOMO}} \cdot{ }^{d}$ Calculated according to $E_{\mathrm{LUMO}}^{\mathrm{opt}}=E_{\mathrm{HOMO}}^{\mathrm{cv}}+E_{\mathrm{g}}^{\mathrm{opt}}$. 


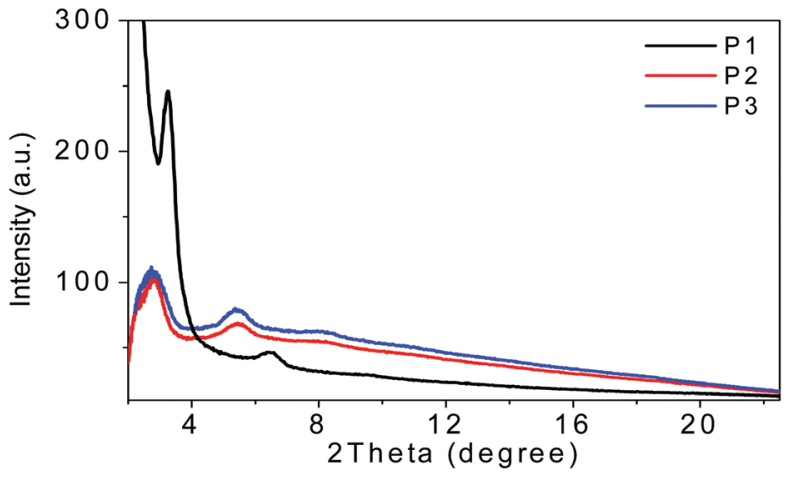

Fig. 2 The GIXD out of plane line-cut profiles of P1, P2 and P3 films on $\mathrm{SiO}_{2} / \mathrm{Si}$ substrates annealed at $200{ }^{\circ} \mathrm{C}$ for $20 \mathrm{~min}$ in an argon-filled glove box.

moderate mobility of $c a .10^{-3}-10^{-2} \mathrm{~cm}^{2} \mathrm{~V}^{-1} \mathrm{~s}^{-1}$ for these polymers, which will be discussed in the next section.

\section{Semiconducting properties}

Bottom gate and bottom contact OFET devices were fabricated to evaluate the semiconducting properties of the polymers.

The mobility $(\mu)$ was calculated in the saturation regime and the results are summarized in Table 2. All polymers exhibited ambipolar properties with slightly better performances in the p-channel operation. Among them, P1, which carries a fluorinated bis-thienylethene group, showed the highest hole and electron mobility of $4.10 \times 10^{-2}$ and $7.63 \times 10^{-3} \mathrm{~cm}^{2} \mathrm{~V}^{-1} \mathrm{~s}^{-1}$, respectively, in agreement with the 2D-GIXD results. The highly fluorinated polymer, P3, showed the lowest hole and electron mobility of $2.03 \times 10^{-3}$ and $2.92 \times 10^{-4} \mathrm{~cm}^{2} \mathrm{~V}^{-1} \mathrm{~s}^{-1}$, respectively, which were an order of magnitude lower than those of P1 and P2. This may have resulted from the lowest solubility $\left(\sim 2-3 \mathrm{mg} \mathrm{ml}^{-1}\right)$ of $\mathbf{P 3}$, which would have a negative influence on the quality of the film. It should be noted that they all showed ideal transfer curves with a linear relationship between the square root of drain current $\left(I_{\mathrm{DA}}{ }^{1 / 2}\right)$ and gate voltage $\left(V_{\mathrm{G}}\right)$ (see ESI $\dagger$ ), implying that the mobility values obtained are reliable. On the other hand, the ratios of $\mu_{\mathrm{h}} / \mu_{\mathrm{e}}$ of $\mathbf{P 1}, \mathbf{P} 2$ and P3 were 5.37, 8.89 and 6.95, respectively. P1 showed the most balanced hole and electron transport properties. The above results indicated that P1 has the best OFET performance among the three polymers, which may be due to the introduction of a vinyl group improving the planarity of the polymer

Table 2 OFET device performance of the polymers

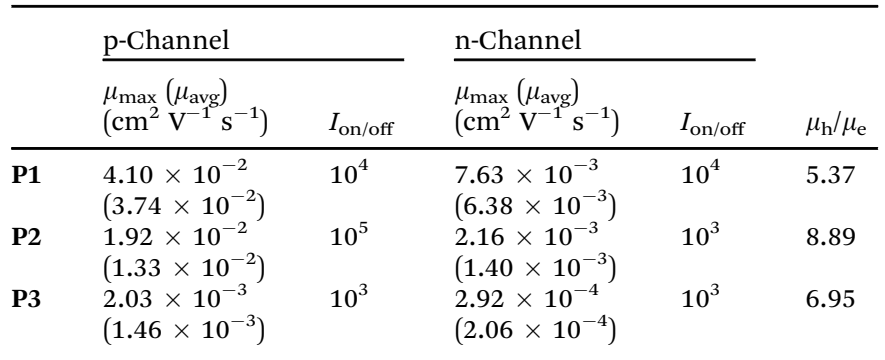

All polymer films were annealed at $200{ }^{\circ} \mathrm{C}$ for 15 min under argon. backbone, which is consistent with the most red-shifted absorption spectra.

\section{Conclusions}

In summary, we successfully optimized the fDT-DPP synthesis by reducing the number of steps and increasing the total yield to $32 \%$. The monomer could be used in the preparation of three new highly fluorinated copolymers by DHAP. Characterization of these polymers confirms the fluorine effect on the electrooptical properties of materials. P3 showed the most significant decreases in the HOMO and LUMO energy levels and a bandgap diminution. The low solubility of this highly fluorinated polymer also induced morphology changes that explained low hole and electron mobilities. These ambipolar copolymers with strong absorption between 600 and $800 \mathrm{~nm}$ could also be utilized as p-type or even n-type semiconductors in various organic solar cells.

\section{Experimental}

\section{3-Bromo-2-(dimethyloctylsyilyl)thiophene (5)}

2,3-Dibromothiophene (20 g, $82.66 \mathrm{mmol})$ is put in a dry $1000 \mathrm{ml}$ round-bottom flask with $200 \mathrm{ml}$ of anhydrous diethyl ether. The solution is then cooled down to $-80{ }^{\circ} \mathrm{C}$, before dropwise addition of $2.5 \mathrm{M} n$-butyllithium solution $(36.4 \mathrm{ml}$, $90.9 \mathrm{mmol}, 1.1 \mathrm{eq}$.$) . The mixture is then left to react for$ 20 minutes before adding $n$-octyldimethylchlorosilane $(18.81 \mathrm{~g}$, $90.9 \mathrm{mmol}, 1.1$ eq.). The mixture can then be left to react overnight while heating up to RT. The product can be purified by a silica plug followed by distillation $\left(110-115{ }^{\circ} \mathrm{C}, 0.35 \mathrm{~mm}\right.$ $\mathrm{Hg})$. The substance obtained is a transparent liquid $(23.43 \mathrm{~g}$, 85\%). ${ }^{1} \mathrm{H}$ NMR $500 \mathrm{MHz}\left(\mathrm{CDCl}_{3}\right) \delta(\mathrm{ppm}): 7.46(\mathrm{~d}, J=4.8 \mathrm{~Hz}, 1 \mathrm{H})$ $7.11(\mathrm{~d}, J=4.8 \mathrm{~Hz}, 1 \mathrm{H}), 1.34-1.24(\mathrm{~m}, 12 \mathrm{H}), 0.92-0.87(\mathrm{~m}, 5 \mathrm{H})$, $0.39(\mathrm{~s}, 6 \mathrm{H})$. NMR data are identical as previously described. ${ }^{13}$

\section{3-Fluoro-2-(dimethyloctylsyilyl)thiophene (6)}

3-Bromo-2-(dimethyloctylsyilyl)thiophene (11.81 g, $35.42 \mathrm{mmol}$, 1 eq.) is put in a $250 \mathrm{ml}$ dry round-bottom flask with $125 \mathrm{ml}$ of anhydrous diethyl ether, which is then cooled to $-78{ }^{\circ} \mathrm{C}$. A 1.7 M tert-butyllithium solution in pentane $(25 \mathrm{ml}, 42.5 \mathrm{mmol}$, 1.2 eq.) is added dropwise, and then the mixture is stirred for 30 minutes at $-80{ }^{\circ} \mathrm{C}$. A precooled solution of $N$-fluorobenzenesulfonimide ( $13.4 \mathrm{~g}, 42.5 \mathrm{mmol}, 1.2 \mathrm{eq}$.) in $275 \mathrm{ml}$ of anhydrous tetrahydrofuran was added dropwise via a canula maintaining a temperature of $-78{ }^{\circ} \mathrm{C}$. The mixture is then left to react overnight while returning to RT. The solution is neutralized by addition of a saturated $\mathrm{NH}_{4} \mathrm{Cl}$ solution and extracted three times with $\mathrm{Et}_{2} \mathrm{O}$. The organic layer was washed with water and brine, dried over anhydrous $\mathrm{MgSO}_{4}$, filtered and concentrated under vacuum. The crude product can be purified by a silica column followed by a C18 column, yielding the desired product as a transparent liquid $(5.40 \mathrm{~g}, 56 \%)$. NMR data are identical as previously described in the literature. ${ }^{13}{ }^{1} \mathrm{H}$ NMR $500 \mathrm{MHz}\left(\mathrm{CDCl}_{3}\right) \delta(\mathrm{ppm}): 7.39(\mathrm{dd}, J=5.0,2.8 \mathrm{~Hz}, 1 \mathrm{H}), 6.85$ 
(dd, $J=5.0,1.6 \mathrm{~Hz}, 1 \mathrm{H}), 1.34-1.25(\mathrm{~m}, 12 \mathrm{H}), 0.90-0.87(\mathrm{~m}, 3 \mathrm{H})$, 0.81-0.78 (m, 2H), $0.31(\mathrm{~s}, 6 \mathrm{H}) .{ }^{19} \mathrm{~F} \mathrm{NMR} 500 \mathrm{MHz}\left(\mathrm{CDCl}_{3}\right)$ $\delta(\mathrm{ppm}):-121(\mathrm{~s}, 1 \mathrm{~F})$. NMR data are identical as previously described. $^{13}$

\section{4-Fluoro-5-(dimethyloctylsyilyl)-2-thiophenecarbonitrile (7)}

3-Fluoro-2-(dimethyloctylsyilyl)thiophene (6) (4.74 g, $17.4 \mathrm{mmol}$, 1 eq.) is put in a round-bottom flask with $500 \mathrm{ml}$ anhydrous diethyl ether, then cooled to $-80{ }^{\circ} \mathrm{C}$. A $n$-butyllithium solution (2.5 $\mathrm{M}$ in hexanes, $7.7 \mathrm{ml}, 19.1 \mathrm{mmol}, 1.1 \mathrm{eq}$.$) is added$ dropwise. The mixture is then stirred for 15 minutes at $-80{ }^{\circ} \mathrm{C}$, then 30 minutes at $0{ }^{\circ} \mathrm{C}$. The flask is cooled back down to $-80{ }^{\circ} \mathrm{C}$ before adding neat phenyl cyanate $(2.71 \mathrm{~g}, 22.6 \mathrm{mmol}$, 1.3 eq.) and stirring at this temperature for 30 minutes, then for 2 hours at $0{ }^{\circ} \mathrm{C}$. The mixture can then be left to react overnight while returning to RT. The reaction is quenched by adding a saturated $\mathrm{NH}_{4} \mathrm{Cl}$ solution and then extracted three times with $\mathrm{Et}_{2} \mathrm{O}$. The organic layer was washed with water and brine, dried over anhydrous $\mathrm{MgSO}_{4}$, filtered and concentrated under vacuum. The product can be isolated by silica column, yielding a transparent liquid $(4.14 \mathrm{~g}, 80 \%) .{ }^{1} \mathrm{H}$ NMR $500 \mathrm{MHz}\left(\mathrm{CDCl}_{3}\right)$ $\delta(\mathrm{ppm}): 7.34$ (d, $J=1.6 \mathrm{~Hz}, 1 \mathrm{H}), 1.34-1.25(\mathrm{~m}, 12 \mathrm{H}), 0.90-0.87$ $(\mathrm{m}, 3 \mathrm{H}), 0.84-0.80(\mathrm{~m}, 2 \mathrm{H}), 0.34(\mathrm{~s}, 6 \mathrm{H}) .{ }^{19} \mathrm{~F}$ NMR $500 \mathrm{MHz}$ $\left(\mathrm{CDCl}_{3}\right) \delta$ (ppm): $118(\mathrm{~s}, 1 \mathrm{~F})$. HRMS (ESI) $\mathrm{m} / z$ calcd for $\mathrm{C}_{15} \mathrm{H}_{24} \mathrm{~F}_{1} \mathrm{~N}_{1} \mathrm{~S}_{1} \mathrm{Si}_{1}[\mathrm{M}+\mathrm{H}]^{+}$298.1456, found 298.1445.

\section{3,6-Bis(4-fluorothiophen-2-yl)-2,5-dihydropyrrolo[3,4-c]pyrrole- 1,4-dione (fDT-DPP)}

$20 \mathrm{ml}$ of 2-methyl-2-butanol is put in a dry twin-neck roundbottom flask equipped with a condenser, then heated up to $105{ }^{\circ} \mathrm{C}$. Sodium $(0.432 \mathrm{~g}, 18.8 \mathrm{mmol}, 4 \mathrm{eq}$.) is added piecemeal to the liquid, which is then stirred until complete digestion. 4-Fluoro-5-(dimethyloctylsyilyl)-2-thiophenecarbonitrile (2.934 g, $9.86 \mathrm{mmol}, 2.1$ eq.) is added rapidly, then diisopropyl succinate $(0.950 \mathrm{~g}, 4.70 \mathrm{mmol}, 1 \mathrm{eq}$.) is added dropwise. The mixture is then left to react overnight at $110{ }^{\circ} \mathrm{C}$. The solution is then cooled down to $60{ }^{\circ} \mathrm{C}$ before adding methanol and stirring for 1 hour. The mixture is then neutralized by adding acetic acid $(1.34 \mathrm{ml}$, $23.5 \mathrm{mmol}, 5$ eq.). The mixture can be filtered by Büchner and washed with methanol. The product is obtained as a purple solid (1.31 g, 83\%). ${ }^{19} \mathrm{~F}$ NMR (470 MHz, DMSO, $\left.60{ }^{\circ} \mathrm{C}\right) \delta$ (ppm) -126.98 (s, 2F). ${ }^{1} \mathrm{H}$ NMR (500 MHz, DMSO, $\left.60{ }^{\circ} \mathrm{C}\right) \delta(\mathrm{ppm})$ : 11.19 (s, 2H), 8.02 (d, $J=1.7 \mathrm{~Hz}, 2 \mathrm{H}$ ), 7.60 (app. t, $J=1.4 \mathrm{~Hz}, 2 \mathrm{H}$ ).

3,6-Bis(4-fluorothiophen-2-yl)-2,5-bis(4-tetradecyloctadecyl)2,5-dihydropyrrolo[3,4-c]pyrrole-1,4-dione (8a)

In a two-neck flask equipped with a condenser, 3,6-bis(4-fluorothiophen-2-yl)-2,5-dihydropyrrolo[3,4-c]pyrrole-1,4-dione (fDT-DPP) (443 mg, $1.32 \mathrm{mmol}, 1$ eq.) was stirred at r.t. in dry DMF ( $9 \mathrm{ml}$, $0.15 \mathrm{M}$ ). 15-(3-Bromopropyl)triacontane (2.09 g, 3 eq.) was added to the mixture followed by dry $\mathrm{K}_{2} \mathrm{CO}_{3}(546 \mathrm{mg}, 3$ eq.) then the mixture was stirred at $100{ }^{\circ} \mathrm{C}$ for $24 \mathrm{~h}$. After cooling at r.t., the reaction was quenched by the addition of $1 \mathrm{M} \mathrm{HCl}$ solution and extracted three times with $\mathrm{Et}_{2} \mathrm{O}$. The organic layer was washed with water and brine, dried over anhydrous $\mathrm{MgSO}_{4}$, filtered and concentrated under vacuum. The solid residue was purified by chromatography on silica gel with Hexane/ $\mathrm{CHCl}_{3}, 70$ to $100 \%$, to afford the desired product as a deep purple solid (730 mg, 45\%). ${ }^{19} \mathrm{~F}$ NMR $(470 \mathrm{MHz}$, $\left.\mathrm{CDCl}_{3}\right) \delta-125.87(\mathrm{~s}, 2 \mathrm{~F}) .{ }^{1} \mathrm{H}$ NMR $\left(500 \mathrm{MHz}, \mathrm{CDCl}_{3}\right) 8.71$ (d, $J=$ $1.7 \mathrm{~Hz}, 2 \mathrm{H}), 7.10-6.87$ (m, 2H), 4.05-3.96 (m, 5H), 1.76-1.65 $(\mathrm{m}, 4 \mathrm{H}), 1.39-1.15(\mathrm{~m}, 127 \mathrm{H}), 0.93-0.83(\mathrm{~m}, 12 \mathrm{H}) .{ }^{13} \mathrm{C}$ NMR $\left(126 \mathrm{MHz}, \mathrm{CDCl}_{3}\right) \delta 160.76,158.61(\mathrm{~d}, J=260.4 \mathrm{~Hz}), 139.24$ (d, $J=2.8 \mathrm{~Hz}), 128.22$ (d, $J=9.4 \mathrm{~Hz}), 123.94(\mathrm{~d}, J=27.5 \mathrm{~Hz}$ ), 109.04 (d, $J=21.5 \mathrm{~Hz}$ ), 108.14, 42.66, 37.25, 33.63, 32.08, 30.58, 30.23, 29.87, 29.83, 29.53, 27.14, 26.82, 22.83, 14.24. HRMS (APPI) $m / z$ calcd for $\mathrm{C}_{78} \mathrm{H}_{134} \mathrm{~F}_{2} \mathrm{~N}_{2} \mathrm{O}_{2} \mathrm{~S}_{2}[\mathrm{M}+\mathrm{H}]^{+} 1233.9928$, found 1233.9942 .

3,6-Bis(4-fluorothiophen-2-yl)-2,5-bis(4-octadecyldocosyl)-2,5dihydropyrrolo[3,4-c]pyrrole-1,4-dione (8b)

In a two-neck flask equipped with a condenser, 3,6-bis(4fluorothiophen-2-yl)-2,5-dihydropyrrolo[3,4-c]pyrrole-1,4-dione (fDT-DPP) (797 mg, $2.37 \mathrm{mmol}, 1$ eq.) was stirred at r.t. in dry DMF (16 ml, $0.15 \mathrm{M})$. 19-(3-Bromopropyl)heptatriacontane (3.35 g, 2.2 eq.) was added in the mixture followed by dry $\mathrm{K}_{2} \mathrm{CO}_{3}$ (720 mg, 2.2 eq.) and then the mixture was stirred at $100{ }^{\circ} \mathrm{C}$ for $24 \mathrm{~h}$. After cooling at r.t., the reaction was quenched by addition of $1 \mathrm{M} \mathrm{HCl}$ solution and extracted three times with $\mathrm{Et}_{2} \mathrm{O}$. The organic layer was washed with water and brine, dried over anhydrous $\mathrm{MgSO}_{4}$, filtered and concentrated under vacuum. The solid residue was purified by chromatography on silica gel with Hexane/CHCl 3,70 to $100 \%$, to afford the desired product as a deep purple solid (1.82 g, 53\%).

${ }^{19} \mathrm{~F}$ NMR (470 $\left.\mathrm{MHz}, \mathrm{CDCl}_{3}\right) \delta-125.87$ (s, 2F). ${ }^{1} \mathrm{H}$ NMR $\left(500 \mathrm{MHz}, \mathrm{CDCl}_{3}\right) 8.71(\mathrm{~d}, J=1.7 \mathrm{~Hz}, 2 \mathrm{H}), 7.03(\mathrm{~d}, J=1.7 \mathrm{~Hz}$, 2H), 4.08-3.91 (m, 4H), 1.77-1.61 (m, 4H), 1.24 (d, $J=5.3 \mathrm{~Hz}$, $148 \mathrm{H}), 0.88$ (t, $J=6.9 \mathrm{~Hz}, 12 \mathrm{H}) .{ }^{13} \mathrm{C} \mathrm{NMR}\left(126 \mathrm{MHz}, \mathrm{CDCl}_{3}\right)$ $\delta 161.00,158.7(\mathrm{~d}, J=260.8 \mathrm{~Hz}), 139.45(\mathrm{~d}, J=2.9 \mathrm{~Hz}), 128.26$ (d, $J=9.1 \mathrm{~Hz}), 123.95$ (d, $J=27.7 \mathrm{~Hz}), 109.16(\mathrm{~d}, J=21.5 \mathrm{~Hz})$, 108.30, 77.41, 77.16, 76.91, 42.72, 37.27, 33.65, 32.09, 30.61, $30.24,29.88,29.83,29.53,27.21,26.83,22.85,14.27$. HRMS (APPI) $m / z$ calcd for $\mathrm{C}_{94} \mathrm{H}_{166} \mathrm{~F}_{2} \mathrm{~N}_{2} \mathrm{O}_{2} \mathrm{~S}_{2}[\mathrm{M}+\mathrm{H}]^{+} 1458.2386$, found 1458.2410.

3,6-Bis(5-bromo-4-fluorothiophen-2-yl)-2,5-bis(4-tetradecyloctadecyl)-2,5-dihydropyrrolo[3,4-c]pyrrole-1,4-dione (9a)

To a solution of (8b) (870 mg, $0.705 \mathrm{mmol}, 1$ eq.) in degassed $\mathrm{CHCl}_{3}(14 \mathrm{ml}, 0.05 \mathrm{M})$ under nitrogen was added portionwise freshly crystallized NBS (376 mg, 3 eq.) and the solution was stirred at $50{ }^{\circ} \mathrm{C}$ in the dark for $1.5 \mathrm{~h}$. Water was added and the mixture was extracted with chloroform. The organic layer was washed with water and brine, dried over $\mathrm{MgSO}_{4}$, filtered and concentrated under vacuum. The residue was purified by chromatography in silica gel with hexane $/ \mathrm{CHCl}_{3}, 50$ to $80 \%$, followed by recrystallization from hexane to give the desired product as a purple solid (491 g, 50\%). ${ }^{19} \mathrm{~F} \mathrm{NMR}(470 \mathrm{MHz}$, $\left.\mathrm{CDCl}_{3}\right) \delta-124.24(\mathrm{~s}, 2 \mathrm{~F}) .{ }^{1} \mathrm{H}$ NMR $\left(500 \mathrm{MHz}, \mathrm{CDCl}_{3}\right) 8.64$ (s, 2H), 3.98-3.91 (m, 4H), 1.73-1.62 (m, 4H), 1.24 (q, $J=8.3$, $5.7 \mathrm{~Hz}, 123 \mathrm{H}), 0.91-0.79(\mathrm{~m}, 12 \mathrm{H}) .{ }^{13} \mathrm{C} \mathrm{NMR}\left(126 \mathrm{MHz}, \mathrm{CDCl}_{3}\right.$ ) $\delta 160.45,156.53(\mathrm{~d}, J=262.1 \mathrm{~Hz}), 138.47(\mathrm{~d}, J=3.3 \mathrm{~Hz}), 127.45$ (d, $J=9.1 \mathrm{~Hz}), 123.18(\mathrm{~d}, J=26.5 \mathrm{~Hz}), 108.12,98.88$ (d, $J=$ $22.9 \mathrm{~Hz}$ ), 42.54, 36.95, 33.37, 31.84, 30.26, 29.99, 29.58, 29.28, 
26.91, 26.59, 22.60, 14.02. HRMS (APPI) $\mathrm{m} / \mathrm{z}$ calcd for $\mathrm{C}_{78} \mathrm{H}_{132} \mathrm{Br}_{2} \mathrm{~F}_{2} \mathrm{~N}_{2} \mathrm{O}_{2} \mathrm{~S}_{2}[\mathrm{M}+\mathrm{H}]^{+}$1391.8130, found 1391.8140.

3,6-Bis(5-bromo-4-fluorothiophen-2-yl)-2,5-bis(4-octadecyldocosyl)2,5-dihydropyrrolo[3,4-c]pyrrole-1,4-dione (9b)

To a solution of (8a) $\left(1.89 \mathrm{~g}, 1.3 \mathrm{mmol}, 1\right.$ eq.) in degassed $\mathrm{CHCl}_{3}$ (36 ml, $0.05 \mathrm{M}$ ) under nitrogen was added portionwise freshly crystallized NBS (484 mg, 2.1 eq.) and the solution was stirred at $50{ }^{\circ} \mathrm{C}$ in the dark for $1.5 \mathrm{~h}$. Water was added and the mixture was extracted with chloroform. The organic layer was washed with water and brine, dried over $\mathrm{MgSO}_{4}$, filtered and concentrated under vacuum. The residue was purified by chromatography in silica gel with hexane $/ \mathrm{CHCl}_{3}, 50$ to $80 \%$, followed by recrystallization from hexane to give the desired product as a purple solid (1.52 g, 73\%). ${ }^{19} \mathrm{~F}$ NMR (470 $\left.\mathrm{MHz}, \mathrm{CDCl}_{3}\right) \delta$ $-124.22(\mathrm{~s}, 2 \mathrm{~F}) .{ }^{1} \mathrm{H}$ NMR (500 MHz, $\left.\mathrm{CDCl}_{3}\right) \delta 8.64(\mathrm{~s}, 2 \mathrm{H})$, 4.00-3.81 (m, 4H), 1.71-1.62 (m, 4H), 1.39-1.15 (m, 148H), 0.88 $(\mathrm{t}, J=6.9 \mathrm{~Hz}, 12 \mathrm{H}) .{ }^{13} \mathrm{C} \mathrm{NMR}\left(126 \mathrm{MHz}, \mathrm{CDCl}_{3}\right) \delta 160.77,156.88$ $(\mathrm{d}, J=257.0 \mathrm{~Hz}), 138.77(\mathrm{~d}, J=3.1 \mathrm{~Hz}), 127.88(\mathrm{~d}, J=9.3 \mathrm{~Hz})$, 123.38 (d, $J=26.5 \mathrm{~Hz}), 108.60,99.00$ (d, $J=22.9 \mathrm{~Hz}), 77.41$, 77.16, 76.91, 42.87, 37.36, 33.80, 32.10, 30.74, 30.27, 29.88, 29.83, 29.52, 27.29, 26.94, 22.84, 14.21. HRMS (APPI) $m / z$ calcd for $\mathrm{C}_{94} \mathrm{H}_{164} \mathrm{Br}_{2} \mathrm{~F}_{2} \mathrm{~N}_{2} \mathrm{O}_{2} \mathrm{~S}_{2}[\mathrm{M}+\mathrm{H}]^{+}$1616.0582, found 1616.0680.

\section{4,4'-Difluoro-2,2'-bithiophene (10)}

To a solution of (4-fluorothiophen-2-yl)dimethyl(octyl)silane (6) (2.476 g, $9.09 \mathrm{mmol}, 1 \mathrm{eq}$.) in dry THF under argon at $-78{ }^{\circ} \mathrm{C}$ was added dropwise $n \mathrm{BuLi}$ (2.5 $\mathrm{M}$ in hexane, $4 \mathrm{ml}, 1.1 \mathrm{eq}$.). The mixture was stirred for $30 \mathrm{~min}$ at r.t. then cooled at $-78{ }^{\circ} \mathrm{C}$. Dry $\mathrm{CuCl}_{2}$ (1.47 g, 1.2 eq.) was added in one shot and the solution was warmed to r.t. and stirred overnight. A $1 \mathrm{M} \mathrm{HCl}$ solution was added to quench the reaction and the resulting mixture was extracted with $\mathrm{Et}_{2} \mathrm{O}$. The organic layer was washed with water and brine then dried over anhydrous $\mathrm{MgSO}_{4}$. The mixture was filtrated, and the solvent was evaporated by vacuum. The residue was filtered on a short pad of silica with hexane and concentrated under vacuum. The residue was dissolved in DCM $(0.8 \mathrm{M})$ and $\mathrm{TBAF}-3 \mathrm{H}_{2} \mathrm{O}(2.1 \mathrm{~g}, 2 \mathrm{eq}$.$) was added and the mixture$ was stirred at r.t. for $2 \mathrm{~h}$. Water was added, and the solution wa's extracted with DCM. The organic layer was washed with water and brine and dried over anhydrous $\mathrm{MgSO}_{4}$, filtered and concentrated under vacuum. The residue was purified by chromatography on silica gel with hexane, followed by recrystallization from $\mathrm{MeOH}$ to give (10) as a white solid (589 $\mathrm{g}, 64 \%)$. m. p. $=61{ }^{\circ} \mathrm{C},{ }^{19} \mathrm{~F}$ NMR $\left(470 \mathrm{MHz}, \mathrm{CDCl}_{3}\right) \delta-126.16(\mathrm{~s}, 2 \mathrm{~F})$. ${ }^{1} \mathrm{H} \mathrm{NMR}\left(500 \mathrm{MHz}, \mathrm{CDCl}_{3}\right) 6.93(\mathrm{~d}, J=1.7 \mathrm{~Hz}, 2 \mathrm{H}), 6.63(\mathrm{t}, J=$ $1.5 \mathrm{~Hz}, 2 \mathrm{H}) .{ }^{13} \mathrm{C}$ NMR $\left(126 \mathrm{MHz}, \mathrm{CDCl}_{3}\right) \delta 157.65(\mathrm{~d}, J=$ $259.3 \mathrm{~Hz}$ ), 135.74 (dd, $J=9.1,2.0 \mathrm{~Hz}), 113.92$ (d, $J=27.5 \mathrm{~Hz}$ ), $103.03\left(\mathrm{~d}, J=21.3 \mathrm{~Hz}\right.$ ). HRMS (APPI) $\mathrm{m} / z$ calcd for $\mathrm{C}_{8} \mathrm{H}_{4} \mathrm{~F}_{2} \mathrm{~S}_{2}[\mathrm{M}]^{+}$ 201.9717, found 201.9737.

\section{5-(Dimethyl(octyl)silyl)-4-fluorothiophene-2-carbaldehyde (11)}

3-Fluoro-2-(dimethyloctylsilyl)thiophene (6) $(2 \mathrm{~g}, 7.35 \mathrm{mmol}$, 1 eq.) was put in a dry $250 \mathrm{ml}$ round-bottom flask with a magnetic stirrer under an argon atmosphere, then $40 \mathrm{ml}$ of dry THF was added. The mixture was cooled to $-80{ }^{\circ} \mathrm{C}$, then
2.5 M $n$-butyllithium (3.1 ml, $7.72 \mathrm{mmol}, 1.05$ eq.) was added dropwise. The mixture was stirred for 30 minutes at $-80{ }^{\circ} \mathrm{C}$, and then dimethyl formamide $(0.740 \mathrm{ml}, 9.56 \mathrm{mmol}, 1.3 \mathrm{eq}$. was added dropwise, then the mixture was stirred overnight and allowed to reach room temperature. The reaction mixture was then neutralized with a saturated $\mathrm{NH}_{4} \mathrm{Cl}$ solution, then extracted with hexanes, washed with water and brine, and dried over $\mathrm{MgSO}_{4}$. The solvent was then removed under vacuum. The product was purified by column chromatography on silica gel, the eluent being a hexanes/diethyl ether mix (90/10), affording the compound as a colorless oil $(Y=80 \%)$. The spectral data was identical with the reported values. ${ }^{13}{ }^{19} \mathrm{~F}$ NMR $\left(470 \mathrm{MHz}, \mathrm{CDCl}_{3}\right) \delta-116.6(\mathrm{~s}, 1 \mathrm{~F})$. ${ }^{1} \mathrm{H}$ NMR (500 MHz, $\left.\mathrm{CDCl}_{3}\right) 9.80(\mathrm{~s}, 1 \mathrm{H}), 7.47$ (d, $\left.J=1.7 \mathrm{~Hz}, 1 \mathrm{H}\right)$, 1.39-1.09 (m, 12H), 0.94-0.68 (m, 5H), 0.35 (s, 6H).

\section{(E)-1,2-Bis(4-fluorothiophen-2-yl)ethene (12)}

Activated $\mathrm{Zn}^{0}(0.78 \mathrm{~g}, 12 \mathrm{mmol}, 2.4$ eq. $)$ was put in a dry threenecked $250 \mathrm{ml}$ flask along with $30 \mathrm{ml}$ of dry THF and put under an argon atmosphere. The reaction medium was cooled to $0{ }^{\circ} \mathrm{C}$, followed by a slow addition of neat $\mathrm{TiCl}_{4}(1.14,6 \mathrm{mmol}, 1.2$ eq.) and then stirred for $1 \mathrm{~h}$ at $65{ }^{\circ} \mathrm{C}$. The mixture was then cooled to room temperature, and a solution of 4-fluoro-5-(dimethyloctylsilyl)-2-thiophenecarboxaldehyde (1.5 g, $5.00 \mathrm{mmol}, 1 \mathrm{eq}$.) dissolved in dry THF was inserted in the reaction medium through a canula. The resulting mixture was then stirred overnight at a temperature of $70{ }^{\circ} \mathrm{C}$. The product was then extracted with hexanes, washed with water and brine, and dried over $\mathrm{MgSO}_{4}$. The solvent was evaporated under vacuum. The crude product was dissolved in $50 \mathrm{ml}$ of dichloromethane, TBAF $3 \mathrm{H}_{2} \mathrm{O}$ (3.16 g, 2 eq.) was added and the mixture was stirred at room temperature for $2 \mathrm{~h}$. The mixture was extracted with hexanes and washed with water and brine. The solvent was then removed under vacuum. The product was purified with column chromatography on silica gel with a hexanes/ethyl acetate mix (98/2) as the eluent, yielding a white powder $(Y=46 \%)$. m. p. $=124{ }^{\circ} \mathrm{C},{ }^{19} \mathrm{~F} \mathrm{NMR}\left(470 \mathrm{MHz}, \mathrm{CDCl}_{3}\right)$ $\delta-126.7$ (s, 2F). ${ }^{1} \mathrm{H}$ NMR $\left(500 \mathrm{MHz}, \mathrm{CDCl}_{3}\right) \delta 6.90$ (s, 2H), 6.82 (dd, $J=1.6,0.7 \mathrm{~Hz}, 2 \mathrm{H}), 6.61-6.56(\mathrm{~m}, 2 \mathrm{H}) .{ }^{13} \mathrm{C} \mathrm{NMR}\left(126 \mathrm{MHz}, \mathrm{CDCl}_{3}\right)$ $\delta 157.87(\mathrm{~d}, J=258.7 \mathrm{~Hz}), 140.16(\mathrm{~d}, J=8.4 \mathrm{~Hz}), 121.42(\mathrm{~d}, J=2.4$ $\mathrm{Hz}$ ), 115.75 (d, $J=26.8 \mathrm{~Hz}), 102.65$ (d, $J=21.4 \mathrm{~Hz}$ ). HRMS (APPI) $m / z$ calcd for $\mathrm{C}_{10} \mathrm{H}_{6} \mathrm{~F}_{2} \mathrm{~S}_{2}\left[\mathrm{M}^{*}\right] 227.9879$, found 227.9864 .

\section{$3,3^{\prime}, 4,4^{\prime}$-Tetrafluoro-2,2'-bithiophene (14)}

The product was obtained from 3,4-dibromothiophene following the described literature procedure ${ }^{8}$ as a white solid (230 mg, 22\% overall yield in 5 steps). m. p. $=96{ }^{\circ} \mathrm{C},{ }^{19} \mathrm{~F} \mathrm{NMR}$ $\left(470 \mathrm{MHz}, \mathrm{CDCl}_{3}\right) \delta-134.98(\mathrm{~d}, J=12.5 \mathrm{~Hz}, 2 \mathrm{~F}),-136.39(\mathrm{~d}, J=$ 12.4 Hz, 2F). ${ }^{1} \mathrm{H}$ NMR (500 MHz, $\left.\mathrm{CDCl}_{3}\right) \delta$ 6.78-6.75 (m, 2H). ${ }^{13} \mathrm{C} \mathrm{NMR}\left(126 \mathrm{MHz}, \mathrm{CDCl}_{3}\right) \delta 145.44(\mathrm{dd}, J=261.8,19.2 \mathrm{~Hz}$ ), $142.16(\mathrm{dd}, J=266.6,20.9 \mathrm{~Hz}), 110.93(\mathrm{ddd}, J=6.9,5.0,3.3 \mathrm{~Hz}$ ), 102.66 (dt-like, $J=15.8,4.2 \mathrm{~Hz}$ ). HRMS (APPI) $\mathrm{m} / \mathrm{z}$ calcd for $\mathrm{C}_{8} \mathrm{H}_{2} \mathrm{~F}_{4} \mathrm{~S}_{2}[\mathrm{M}]^{+}$237.9529, found 237.9562.

\section{Conflicts of interest}

There are no conflicts to declare. 


\section{Acknowledgements}

The authors acknowledge the Natural Sciences and Engineering Research Council of Canada (NSERC), Université Laval (APOGEE, Sentinelle Nord) and the Canadian Institute for Advanced Research (CIFAR). We also want to thank Mathieu Mainville for DFT calculations.

\section{Notes and references}

1 D. G. Farnum, G. Mehta, G. G. I. Moore and F. P. Siegal, Attempted reformatskii reaction of benzonitrile, 1,4-diketo3,6-diphenylpyrrolo[3,4-c]pyrrole. A lactam analogue of pentalene, Tetrahedron Lett., 1974, 15, 2549-2552.

2 A. Tang, C. Zhan, J. Yao and E. Zhou, Design of Diketopyrrolopyrrole (DPP)-Based Small Molecules for Organic-SolarCell Applications, Adv. Mater., 2017, 29, 1600013.

3 I. Kang, H. J. Yun, D. S. Chung, S. K. Kwon and Y. H. Kim, Record High Hole Mobility in Polymer Semiconductors via SideChain Engineering, J. Am. Chem. Soc., 2013, 135, 14896-14899.

4 H. J. Yun, S. J. Kang, Y. Xu, S. O. Kim, Y. H. Kim, Y. Y. Noh and S. K. Kwon, Dramatic Inversion of Charge Polarity in Diketopyrrolopyrrole-Based Organic Field-effect Transistors via Simple Nitrile Group Substitution, Adv. Mater., 2014, 26, 7300-7307.

5 H. Choi, S.-J. Ko, T. Kim, P.-O. Morin, B. Walker, B. H. Lee, M. Leclerc, J. Y. Kim and A. J. Heeger, Small-Bandgap Polymer Solar Cells with Unprecedented Short-Circuit Current Density and High Fill Factor, Adv. Mater., 2015, 27, 3318-3324.

6 M. Lee, T. Kim, H. Van, T. Nguyen, H. W. Cho, K.-K. Lee, J.-H. Choi, B. S. Kim and J. Y. Kim, Regio-regular alternating diketopyrrolopyrrolebased D1-A-D2-A terpolymers for the enhanced performance of polymer solar cells, RSC Adv., 2019, 9, 42096-42109.

7 N. Leclerc, P. Chávez, O. A. Ibraikulov, T. Heiser and P. Lévêque, Impact of Backbone Fluorination on $\pi$-Conjugated Polymers in Organic Photovoltaic Devices: A Review, Polymers, 2016, 8, 11.

8 T. Olla, O. A. Ibraikulov, S. Ferry, O. Boyron, S. Méry, B. Heinrich, T. Heiser, P. Levéque and N. Leclerc, Benzothiadiazole Halogenation Impact in Conjugated Polymers, a Comprehensive Study, Macromolecules, 2019, 52, 8006-8016.

9 C. Sun, F. Pan, S. Chen, R. Wang, R. Sun, Z. Shang, B. Qiu, J. Min, M. Lv, L. Meng, C. Zhang, M. Xiao, C. Yang and Y. Li, Achieving Fast Charge Separation and Low Nonradiative
Recombination Loss by Rational Fluorination for HighEfficiency Polymer Solar Cells, Adv. Mater., 2019, 31, 1905480.

10 Z. Fei, P. Boufflet, S. Wood, J. Wade, J. Moriarty, E. Gann, E. L. Ratcliff, C. R. McNeill, H. Sirringhaus, J.-S. Kim and M. Heeney, Influence of Backbone Fluorination in Regioregular Poly(3-alkyl-4-fluoro)thiophenes, J. Am. Chem. Soc., 2015, 137(21), 6866-6879.

11 B. Jiang, C. C. Du, M. J. Li, K. Gao, L. Kou, M. Chen, F. Liu, T. P. Russell and H. Wang, Synthesis of fluorinated diphenyldiketopyrrolopyrrole derivatives as new building blocks for conjugated copolymers, Polym. Chem., 2016, 7, 3311.

12 J.-R. Pouliot, B. Sun, M. Leduc, A. Najari, Y. Li and M. Leclerc, A high mobility DPP-based polymer obtained via direct (hetero)arylation polymerization, Polym. Chem., 2015, 6, 278-282.

13 T. Bura, S. Beaupré, M.-A. Légaré, O. A. Ibraikulov, N. Leclerc and M. Leclerc, Theoretical Calculations for Highly Selective Direct Heteroarylation Polymerization: New Nitrile-Substituted Dithienyl-Diketopyrrolopyrrole-Based Polymers, Molecules, 2018, 23, 2324.

14 T. Bura, S. Beaupré, O. A. Ibraikulov, M.-A. Legaré, J. Quinn, P. Levéque, T. Heiser, Y. Li, N. Leclerc and M. Leclerc, New Fluorinated Dithienyldiketopyrrolopyrrole Monomers and Polymers for Organic Electronics, Macromolecules, 2017, 50, 7080-7090.

15 X. Wang, B. Jiang, C. Du, X. Ren, Z. Duan and H. Wang, Fluorinated dithienyl-diketopyrrolopyrrole: a new building block for organic optoelectronic materials, New J. Chem., 2019, 43, 16411.

16 Y. Zou, D. Gendron, R. Badrou-Aïch, A. Najari, Y. Tao and M. Leclerc, A High-Mobility Low-Bandgap Poly(2,7-carbazole) Derivative for Photovoltaic Applications, Macromolecules, 2009, 42(8), 2891-2894.

17 Y. Gao, J. Bai, Y. Sui, Y. Han, Y. Deng, H. Tian, Y. Geng and F. Wang, High Mobility Ambipolar DiketopyrrolopyrroleBased Conjugated Polymers Synthesized via Direct Arylation Polycondensation: Influence of Thiophene Moieties and Side Chains, Macromolecules, 2018, 51, 8752-8760.

18 K. Kawashima, T. Fukuhara, Y. Suda, Y. Suzuki, T. Koganezawa, H. Yoshida, H. Ohkita, I. Osaka and K. Takimiya, J. Am. Chem. Soc., 2016, 138, 10265-10275.

19 T. Lei, J.-H. Dou, X.-Y. Cao, J.-Y. Wang and J. Pei, A BDOPVBased Donor-Acceptor Polymer for High-Performance n-Type and Oxygen-Doped Ambipolar Field-Effect Transistors, Adv. Mater., 2013, 25, 6589-6593. 